\title{
Community Perceptions and Priorities for Managing Water and Environmental Resources in the River Njoro Watershed in Kenya
}

\author{
M. W. Jenkins ${ }^{1}$, F. K. Lelo ${ }^{2}$, L.W. Chiuri ${ }^{2}$, W. A. Shivoga ${ }^{2}$ and S. N. Miller ${ }^{3}$ \\ ${ }^{1}$ Assist. Res. Engineer, Civil \& Environ. Engin., University of California, Davis, CA 95616; \\ Tel (530) 754-6427, Fax (530) 752-7872, email: mwjenkins@ucdavis.edu \\ ${ }^{2}$ Associate Professor and Sr Lecturers, respectively, in Environmental Science, Egerton \\ University, Njoro, Kenya; Tel (+254) 51 62085, emails: lelo@africaonline.co.ke, \\ drchiuri@yahoo.com, shivogawa@yahoo.co.uk \\ ${ }^{3}$ Assist. Professor, Rangeland Ecology \& Watershed Mgmt, University of Wyoming, \\ Laramie, WY 82071; Tel (307) 766-4274, Fax (307) 766-6403, email: snmiller@uwyo.edu
}

\section{Abstract}

The Njoro Watershed, typical of the semi-arid basins in the Rift Valley of Kenya, is undergoing a new phase of rapid land use change in the uplands portion of the watershed, and on-going significant growth in both rural and urban populations. Considerable negative environmental impacts are occurring, in particular to the quantity and quality of river water. Domestic, livestock, commercial, industrial, and institutional water users in the basin are affected, as well as important downstream habitat in Lake Nakuru, a large shallow saline lake designated a Ramsar wetlands site of international importance. In response to these concerns, a joint US-Kenyan multidisciplinary applied research project called Sustainable Management of Watersheds Collaborative Research Support Program (SUMAWA-CRSP) was established. SUMAWA aims, over the next 3-5 years, to demonstrate improved and integrated management of water and environmental resources in the Njoro Watershed through local stakeholder participation and action supported by scientific information and analyses.

Preliminary results from elements of the SUMAWA planned process for stakeholder participation in management of the Njoro Watershed are presented. A mixture of participatory methods, discussion forums, awareness-raising activities, and local capacity building are being undertaken to address some of the challenges involved in engaging local stakeholders and communities in watershed action planning. The first phase of activities adapts Participatory Rural Appraisal methods to assess local residents' interests in and perceptions of the current condition of river water quality and quantity, of problems and their causes, and opportunities for local action in six different communities along the length of the watershed.

\section{Introduction}

Stakeholder participation in water resources management in developing countries is being promoted in efforts to decentralize decision-making and improve the planning, development, and sustainable use of water and environmental resources (UNWWAP 2003). Successful models of stakeholder watershed action planning in Africa have 
yet to emerge from new experimentation underway in several countries. Early evidence from Zimbabwe suggests many risks and challenges (Kujinga 2002).

A bottom-up approach that engages local populations in the planning process can be particularly important in developing countries where reducing poverty and enhancing livelihoods are important goals for water and environmental resources management. The welfare of poorer segments of the population, often marginalized from formal planning processes, tends to be directly tied to the condition of and access to water and other common pool resources in localized areas of watersheds.

Stakeholder collaboration. Involving watershed stakeholders in collaborative decision-making does not always succeed in achieving an agreed course of action. Reasons for failure include: attributes of the issues being addressed, failure to address underlying sources of conflict, stakeholder unwillingness to participate, procedural characteristics of the process, composition of stakeholders, time, resources and political will, and issues of trust (Carson 1999; Leach \& Sabatier 2003; Smutko et al. 2002). Reviewing the success of US community-based watershed management projects, Huckett et al. (2003) reports two fundamental factors: 1) the inclusiveness and effectiveness of the community involvement process in defining the problem and formulating solutions; and 2) the compatibility among stakeholders regarding knowledge/perceptions, values/interests, and power relationships.

An analysis of sources of conflict in water management shows that disagreements on the course of action can arise from three fundamental sources: factual disagreement, conflicting goals (interests and values), and relational aspects (distrust and power struggles) (Mostert 1998). The common and preferred conflict management procedure is facilitated open discussions, negotiations, and mixes of the two, using techniques and formats that allow stakeholders to arrive at a consensus on action.

Participatory methods. Participatory methods which involve discourse and democratic deliberation among watershed stakeholders have shown substantial promise in the US and Europe (Smolko et al. 2002; Collentine et al. 2002). The approach draws on theories of adult education, group dynamics and learning, collective action, and consensus decision-making. In developing countries, participatory methods have been successful in attaining high levels of participation and collaboration in development projects, stimulating communities to self-mobilize and take independent action (Chambers 1992).

SUMAWA Project. The SUMAWA project, established in 2002, is a collaborative research project between US and Kenyan scientists and engineers (Universities of Wyoming, California-Davis, and Utah State in the US, and Egerton and Moi Universities in Kenya), and Kenyan government agencies (Kenya Wildlife Service and Fisheries Department). Core funding is from the US Agency for International Development. The project is based at Egerton University located in the Njoro Watershed. The project's planned public involvement process is fundamental to its aim to demonstrate improved water quantity and quality conditions in the Njoro River Watershed. In parallel with the stakeholder process, the project is developing scientific information, data and analysis methods, technologies, and decision-support tools to support stakeholder decision-making. Research outcomes will include 
lessons for the development of a workable process model and methods for successful stakeholder participation in watershed action planning in Kenya and similar settings.

\section{Njoro Watershed Description}

Information is summarized from Chemelil (1995) and SAPS-JBIC (2002). The River Njoro spans a distance of about $60 \mathrm{~km}$ from its origin in the native forests of the Eastern Mau Escarpment (elevation of 2700-3000 meters (m)) to its terminus at Lake Nakuru in the Rift Valley floor (1759 m) (Fig.1). The watershed covers an estimated $302 \mathrm{~km}^{2}$ of the Lake Nakuru Basin (LNB), providing 39\% (more than its \% area) to the Lake's annual run-off (Fig.1b). Long-term mean annual rainfall varies from 1200 $\mathrm{mm}$ in the upper reaches to $800 \mathrm{~mm}$ at Lake Nakuru, distributed tri-modally with peaks in April (biggest), August (second) and November (smallest). The hot dry season runs January to March. Potential maximum evapotranspiration $\left(\mathrm{ET}_{\mathrm{m}}\right)$ over the Njoro Watershed, estimated at $1150 \mathrm{~mm} / \mathrm{year}$ (from Kenya pan readings, Egerton University, 1965-1993), peaks in March. With annual $\mathrm{ET}_{\mathrm{m}}$ exceeding rainfall in the valley, upper catchments of watersheds such as the Njoro provide a critical net rainfall capture zone for water resources in the semi-arid Rift Valley.

The river has historically become influent as it approaches its terminus near the Lake Nakuru National Park (LNNP) boundary, and generally is thought to loose much of its flow in the porous fissured zones of the Rift Valley floor, contributing to water tables around the lake. In recent years higher reaches of the river have run dry and boreholes have failed, causing alarm and resulting in periodic water rationing.
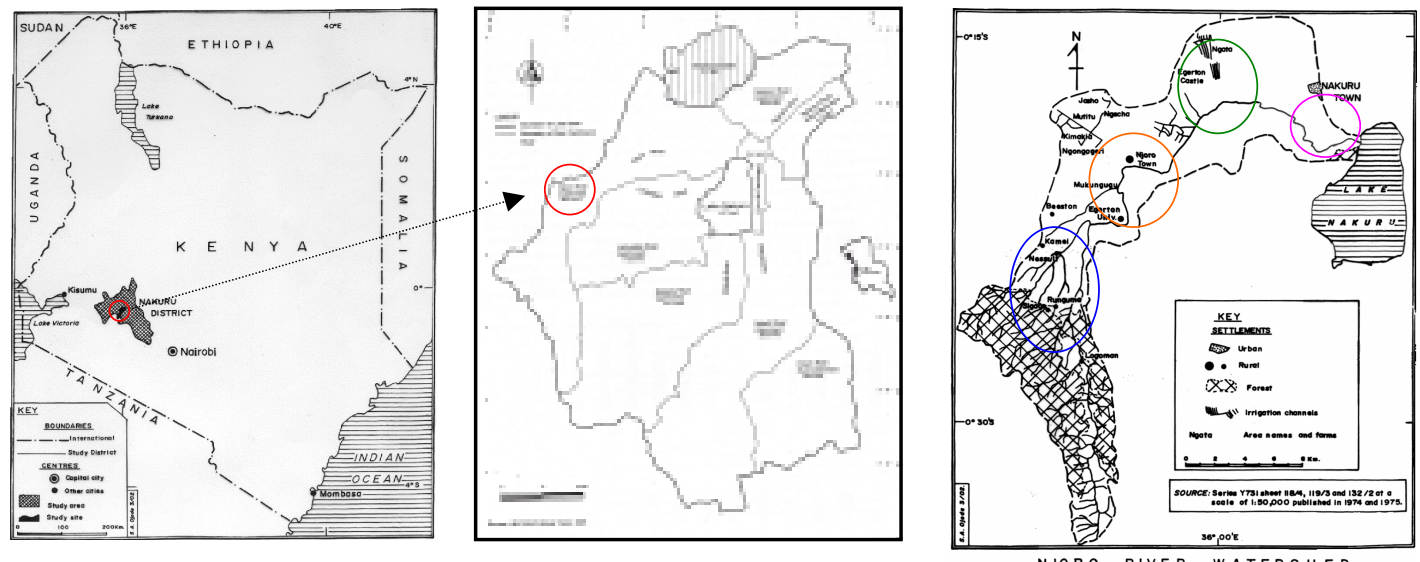

Figure 1. (a) Location of River Njoro Watershed in Kenya, (b) Lake Nakuru Basin, (c) Communities in the Watershed

(Nessuit - blue, Njoro Town - orange, Ngata -Green, Kaptembwo/Baruti - pink)

Human population, land use, and livestock trends. The watershed population, excluding Nakuru Municipality, was estimated at 70-75,000 in 1999 (Table 1). Between 1970 and 1987, forested cover was reduced from an estimated 60\% to 14\% in the upper $168 \mathrm{~km}^{2}$ of the watershed while agricultural land increased from $35 \%$ to $62 \%$ and urban settlement from 5\% to 24\% (Chemelil 1995). Similar trends have occurred elsewhere in Nakuru District. A decline in forest cover from 47\% to 15\% between 1970-1998 was estimated for all of LNB (SAP-JICB 2002). Agriculture, mostly small-scale farms (non-existent in 1970), now dominates LNB land use, 
Table 1. Estimated Population and Annual Population Growth Rates

\begin{tabular}{|l|l|l|l|l|l|l|}
\hline Unit & Unit Details & Hist. Pop & '69-79 & '79-89 & '89-99 & 1999 Pop \\
\hline $\begin{array}{l}\text { Nakuru Municipality } \\
\text { (NM) }\end{array}$ & $\begin{array}{l}\text { Includes whole of Division } \\
\text { except LNNP population }\end{array}$ & $\begin{array}{l}47,151 \\
(1969)\end{array}$ & $7.0 \%$ & $5.9 \%$ & $2.6 \%$ & $\begin{array}{l}212,986 \\
\left(203,817^{\mathrm{a}}\right)\end{array}$ \\
\hline $\begin{array}{l}\text { River Njoro } \\
\text { Watershed (w/o NM) }\end{array}$ & $\begin{array}{l}\text { Includes NM Baruti Sub- } \\
\text { location }\left(\sim 290 \mathrm{~km}^{2}\right)\end{array}$ & $\begin{array}{l}30,000^{*} \\
(1979)\end{array}$ & $\mathrm{Na}$ & $6.4 \%$ & $2.2 \%$ & $\begin{array}{l}70- \\
75,000 *\end{array}$ \\
\hline $\begin{array}{l}\text { Njoro, Mukungugu \& } \\
\text { Nessuit Sub-locations }\end{array}$ & $\begin{array}{l}151 \mathrm{~km}^{2} \text { upper watershed } \\
\text { above Ngata Sub-location }\end{array}$ & $\begin{array}{l}15,100^{*} \\
(1979)\end{array}$ & $\mathrm{Na}$ & $8.2 \%$ & $3.3 \%$ & 46,547 \\
\hline
\end{tabular}

* Calculated from densities and 1999 administrative area, as boundaries changed in each census.

${ }^{a}$ Excludes Baruti Sub-Location. Source: Central Bureau of Statistics, Nairobi, Kenya

estimated at $47 \%$ in 1996 and $65 \%$ in 2002 . LNB forest now stands at about $5 \%$ (SAP-JICB 2002). The growing population, 40-60\% of which are estimated to lived below the absolute poverty line (1997 Nakuru District data, ILRI 2002), puts ever increasing demands on natural resources within the watershed. Rift Valley Province has the highest proportion in Kenya (29\%) of over 20 year olds who have never attended school (CBS 2003).

Livestock provides an important component of income for poor farm households (ILRI 2002). Livestock growth, much of which is free-range and nearly all watered directly at the river, has paralleled human population growth, and average holdings suggest as many as 30,000 cattle now permanently inhabit the watershed (ILRI 2002). Further livestock pressure is created by nomadic Massai pastoralists who have pasture rights to public lands in the upper catchment.

Local communities and stakeholders. The watershed population of between 7075,000 has been grouped into six communities starting at the top with Nessuit, in the middle with Mwigito, Rumwe (sections of Njoro Town), and Ngata, and at the bottom with Kaptembwo and Baruti (parts of Nakuru Municipality) (Fig.1c). These communities utilize watershed resources in different ways, and consequently have different outlooks on the health and use of the river and surrounding landscape. Smallholders in the uppermost community of Nessuit, for instance, are primarily subsistence farmers who arrived during a wave of politically motivated settlement in the 1990's (Daniels \& Bassett 2002). Njoro Town, in the middle of the watershed, is a relatively large, growing community that houses Egerton University and has several larger farms. Near the outlet of the river lie the relatively poor, rapidly growing semiurban communities of Kaptembwo and Baruti.

In addition to local communities, other watershed stakeholders with an interest in water and land management include:

- Several large-scale commercial farmers in the lower section.

- Industrial and commercial enterprises centered mostly around Njoro Town and Nakuru Municipality, comprising dairies, a canning factory, slaughterhouses.

- Egerton University, operating a large commercial agricultural farm research facility on about 8000 acres with a campus population of about 8,000 .

- Other public sector institutions located in the middle and lower sections

- Ministry of Forestry which oversees public lands and national forest reserves (Eastern Mau Forest) in the upper-most sections of the watershed.

- Kenya Wildlife Service, owners and managers of Lake Nakuru National Park 
- Non-governmental organizations including Ogiek Welfare Council (OWC), Forest Action Network (FAN), Friends of Mau Forest (FOMAWA), Kenya Forest Working Group (KFWG), local Dioceses of the Catholic and Anglican Churches.

\section{Planned Public Involvement Processes}

SUMAWA's stakeholder involvement component aims to promote adaptive learning, dialogue, and consensus decision-making among stakeholders, local communities, government officials, and project scientists in order to develop a collaborative watershed-wide action plan that builds on and integrates individual local community action plans. To achieve this, several parallel public involvement processes are envisioned:

- Participatory appraisal of local community interests, problems, causes and proposed actions related to water issues in the watershed

- Tiered stakeholder-community workshops bringing together representatives of each community with government officials, scientists, and stakeholders

- Exchange visits between communities within the watershed

- Community leadership training

- Seminars and workshops on action opportunities, environmental laws and rights, and scientific findings

- Demonstration and trial of promising interventions at household, farm and community level

The community participatory appraisal process is the crucial first step laying the foundation for inclusive and effective involvement of local residents and marginalized groups in subsequent activities. The main dialogue and negotiation processes will occur in a series of tiered workshops to harmonize goals, and develop consensus solutions on system-wide watershed action plans. Other activities listed above are intended to support the deliberation and negotiation process by introducing new knowledge and solution opportunities, changing perceptions, and building skills to increase collaboration, convergence of interests, and consensus on action. Interaction with project scientists as active participants is a key ingredient in many of the proposed processes.

Community participatory appraisal process. Participatory Rural Appraisal (PRA) methods used widely in Kenya and other developing countries were adapted to focus specifically on river and watershed conditions (Lelo et al. 2000). Community leaders were contacted and invited to organize a voluntary group of representative community members to participate in discussion exercises. Data gathering (community map; benefits analysis; resource flow chart; seasonal calendar; institutional analysis), problem ranking (problem list; causes and coping strategies; trends; pair wise ranking matrix), and opportunity assessment tools (opportunity listing, assessment, and ranking; action planning) were used in a series of 2 hour meetings to elicit information, identify priority problems, and explore locally available action opportunities in each of the six communities. About 25-40 residents in each community participated in the PRA process over a 2 week period. 


\section{Findings: Community Perceptions and Priorities}

The PRA exercises have been completed in Baruti, Rumwe and Mwigito communities, located in the lower and middle sections. PRAs are being organized in the remaining communities. Here, we present an initial assessment of perceptions, priorities and possibilities for action mainly from these three middle/lower watershed communities. Emerging issues have focused on the riparian corridor and river water conditions, but are likely to enlarge as the process continues to include land management in the upper catchment and groundwater.

Local interests in open-access water and riparian resources. The benefits analysis exercise revealed an extensive list of direct uses of in-river water, river bank/bed materials, and riparian buffer vegetation by local community members and other actors in the watershed:

- fetching water for domestic use, and bathing and laundry at river side (D)

- watering large livestock at the river (L-L)

- fetching river water for or watering small livestock at the river (L-S)

- fetching water for transport and sale (S)

- direct withdrawals for small-scale dry season irrigation near banks (IR)

- fetching water for construction and building houses (BL)

- cultural uses of river water such as baptisms, circumcision ceremonies (C)

- extracting sand from river for construction (SD)

- extracting rocks and gravel from river for construction (RK)

- humus soil gathering along banks for tree nurseries (HM)

- gathering fuel wood for domestic use, some also for sale, charcoal making (FW)

- grass fodder collection along river banks for sale (FDC)

- grass fodder livestock grazing along river banks (FDG)

- growing vegetables at river side(e.g., potatoes) (VG)

- growing maize crop at river side (subsistence crop) (CR-M)

- growing wheat crop at river side (for cash, pesticides commonly used) (CR-W)

- gathering wood, bark, parts of tree materials for house building (BM)

- gathering medicinal herbs and other plant matter (roots, tree bark, leaves) (MP)

- bee-keeping for honey for sale (HY)

These uses are critical for many poor households to meet very basic domestic human and livestock needs, and supplement income as part of economic survival strategies. Table 2 shows the distribution of these uses (coded in parenthesis above) by community and sub-group, and by other commercial, public and institutional users in the watershed. Two additional water resource uses are included for this latter group:

- groundwater extraction by borehole $(\mathrm{GW})$

- wastewater point discharges to the river (WW)

Discussions revealed that "outsiders" regularly exploit water, river bed, and riparian vegetation (medicinal herbs, firewood and fodder) within a community's local riparian zone. Local resource extractions by "outsiders" tend to be: a) bringing livestock to local watering points and to graze on riparian vegetation, b) extracting river water for commercial transport and sale elsewhere, c) extracting bank and bed materials for sale or for commercial, public and private purposes. 
Table 2. Resource Extraction and Use by Community Members, Institutions, Industries, Commercial and Public Sector Actors Along the Njoro River (SUMAWA PRA Reports, 2003).

\begin{tabular}{|c|c|c|c|c|c|c|c|c|c|c|c|c|c|c|c|c|c|c|c|c|c|c|}
\hline Community & $\begin{array}{l}\text { Population Sub-group } \\
\text { or Organization }\end{array}$ & Sur & ace W & $\begin{array}{r}\text { Vater } \\
\mathrm{R}\end{array}$ & $\begin{array}{l}\text { Extı } \\
\text { ver }\end{array}$ & actic & ons fr & om & $\begin{array}{r}\text { Rive } \\
1\end{array}$ & $\begin{array}{l}\text { r Bed } \\
\text { Materi }\end{array}$ & $\begin{array}{l}\text { Bank } \\
\text { lls }\end{array}$ & & Ripari & ian Zor & ne - T & rees/Ves & getation/C & ultiva & tion & & GW & WW \\
\hline & & $\mathrm{D}$ & L-L & L-S & $\mathrm{S}$ & IR & $\mathrm{BL}$ & $\mathrm{C}$ & SD & RK & HM & FW & FDC & FDG & $\mathrm{VG}$ & CR-M & CR-W & $\mathrm{BM}$ & MP & $\mathrm{HY}$ & & \\
\hline Barut & Women & $* \mathrm{~d}$ & $*$ & & & $*$ & $* \mathrm{~d}$ & & $* \mathrm{~d}$ & & & $* \mathrm{~d}$ & & & $* \mathrm{~d}$ & & & $*$ & $*$ & & & \\
\hline Ngata & Women & *? & $*$ & $* \mathrm{~d}$ & & & & & & & & & & & $* \mathrm{~d}$ & $* \mathrm{~d}$ & & & $* \mathrm{~d}$ & & & \\
\hline Rumwe & Women & $* d$ & & & & $* \mathrm{~d}$ & $* \mathrm{~d}$ & & & & & $* \mathrm{~d}$ & & $*$ & & & & & $* \mathrm{~d}$ & & & \\
\hline Mwigito & Women & $* \mathrm{~d}$ & $* \mathrm{~d}$ & & & $*$ & & & & $* \mathrm{~d}$ & & $*_{\mathrm{d}}$ & & & & & & & & & & \\
\hline Barut & Men & $*$ & $* \mathrm{~d}$ & & & $* ?$ & $* \mathrm{~d}$ & & $* \mathrm{~d}$ & & & & & & & & & $* \mathrm{~d}$ & $* \mathrm{~d}$ & $* \mathrm{~d}$ & & \\
\hline Ngata & Men & $*$ & $* \mathrm{~d}$ & & $* ?$ & & & & & & & & & & & $* \mathrm{~d}$ & $* \mathrm{~d}$ & & $* d$ & $* \mathrm{~d}$ & & \\
\hline Rumwe & Men & & $* \mathrm{~d}$ & & & $* \mathrm{~d}$ & $* \mathrm{~d}$ & & $* \mathrm{~d}$ & $* \mathrm{~d}$ & & & & $* \mathrm{~d}$ & & & & & $* \mathrm{~d}$ & & & \\
\hline Mwigito & Men & $\mathrm{d}$ & $* \mathrm{~d}$ & & & $* \mathrm{~d}$ & & & & $* \mathrm{~d}$ & & $* \mathrm{~d}$ & & $* \mathrm{~d}$ & & & & & & & not appli & icable \\
\hline Barut & Youth & $*$ & $*$ & & $* \mathrm{~d}$ & $*$ & & & $* \mathrm{~d}$ & & & & & & & & & $* \mathrm{~d}$ & $* \mathrm{~d}$ & & & \\
\hline Ngata & Youth & $*$ & & $* \mathrm{~d}$ & $* ?$ & & & & & & & & & & & & & & & & & \\
\hline Rumwe & YgMen & $* \mathrm{~d}$ & $*$ & & $* \mathrm{~d}$ & & & & & & & & $* \mathrm{~d}$ & $*$ & & & & & & & & \\
\hline Mwigito & YgMen & & & & & & & & & & e Mwi & igito & "Other & s") & & & & & & & & \\
\hline Barut & Others $^{\mathrm{a}}$ & & $*$ & & $* \mathrm{~d}$ & & $* \mathrm{~d}$ & $* \mathrm{~d}$ & $* \mathrm{~d}$ & & & $* \mathrm{~d}$ & & & & & & & $* d$ & & & \\
\hline Ngata & Others $^{\mathrm{a}}$ & & & & & & & & & & & & & & & & & & & & & \\
\hline Rumwe & Others $^{b}$ & & $* \mathrm{~d}$ & & $* \mathrm{~d}$ & & $* \mathrm{~d}$ & & $* \mathrm{~d}$ & $* \mathrm{~d}$ & $* \mathrm{~d}$ & $* \mathrm{~d}$ & $* \mathrm{~d}$ & $* d$ & & & & & $* \mathrm{~d}$ & & & \\
\hline Mwigito & Others $^{c}$ & $* \mathrm{~d}$ & $* \mathrm{~d}$ & & $* \mathrm{~d}$ & $* \mathrm{~d}$ & & & & $* \mathrm{~d}$ & & $* \mathrm{~d}$ & & $* \mathrm{~d}$ & & & & & & & & \\
\hline Rumwe & Rumwe Society & $*$ & $*$ & & & $*$ & & & & & & & & & & $*$ & $*$ & & & & $*(2)$ & \\
\hline Rumwe & Nakuru County Council & $*$ & & & & & & & $*$ & $*$ & & & & & & & & & & & $*(?)$ & \\
\hline Rumwe & FAN & & & & & & & & & & $*$ & & & & & & & & & & & \\
\hline Mwigito & Mwihoti Water Project & & & & & & & & & & & & & & & & & & & & $*(1)$ & \\
\hline Mwigito & Kiragu Dairy Farm & & $*$ & & & & & & & & & & & & & & & & & & $*(1)$ & $?$ \\
\hline Mwigito & Kiptanui Dairy Farm & & $*$ & & & & & & & & & & & & & & & & & & $*(1)$ & $?$ \\
\hline Mwigito & Njoro Canning Factory & & & & & & & & & & & & & & & & & & & & $*(1)$ & $*$ \\
\hline Mwigito & KH Flower Company & $*$ & & & & & & & & & & & & & & & & & & & $*(1)$ & $?$ \\
\hline Mwigito & Egerton University & $*$ & $*$ & & & $*$ & & & & & & & & & & $*$ & $*$ & & & & $*(10+)$ & $*$ \\
\hline Mwigito & KARI & $*$ & & & & $*$ & & & & & $*$ & & & & & $*$ & $*$ & & & & $*(3)$ & $?$ \\
\hline Mwigito & Tim-sales Enterprises & & & & & & & & & & & & & & & & & & & & $*(1)$ & \\
\hline Mwigito & Gikombo Farm & $*$ & & & & & & & & & & & & & & & & & & & & \\
\hline
\end{tabular}

*: use activity by group; $\mathbf{d}$ : use decisions made by group; ?: likely decision maker or user, but unclear from report; (\#): number of boreholes adjacent to river 
Table 3. Community Problems and Priorities for Managing the Njoro Watershed (SUMAWA PRA Reports, 2003).

\begin{tabular}{|c|c|c|c|c|}
\hline \multirow[t]{2}{*}{ Problem } & \multirow[t]{2}{*}{ Perceived Causes \& Issues } & \multicolumn{3}{|c|}{ Ranking } \\
\hline & & B & $\mathrm{R}$ & M \\
\hline Insufficient (river) water & $\begin{array}{l}\text { River runs dry periodically (Barut); lack of alternative sources; poor river protection; shallow dams upstream } \\
\text { (Barut); drought; irrigation upstream; sand scooping; overstocking of animals; outsiders extracting water for sale, } \\
\text { too many users (Barut); obstruction of river flow (Rumwe) }\end{array}$ & 1 & 7 & \\
\hline Low income & $\begin{array}{l}\text { Over-reliance on milk \& maize, farm employment, \& sawmills employment (which have shut down); reliance on } \\
\text { middlemen for marketing; lack of storage facilities for wheat; lack of market for produce. }\end{array}$ & & 1 & \\
\hline Water quality \& quantity & Poor quality water, not enough - scarcity esp. in January-February dry season; water siltation. & & & 1 \\
\hline $\begin{array}{l}\text { Water-borne diseases } \\
\text { (consuming polluted river water) }\end{array}$ & $\begin{array}{l}\text { Run-off with dirt including human waste; dirty water from washing of vehicles, laundry, \& bathing in river; dirty } \\
\text { effluents; lack of latrines; soil erosion; sand extraction makes river dirty; dumping of waste in river. }\end{array}$ & 2 & & 3 \\
\hline Poor community cooperation & Poor leadership; ignorance about group value. & & 2 & \\
\hline Fuel wood (scarcity) & Deforestation; failure to plant trees on own shambas (fields); closing down sawmills. & & 4 & 2 \\
\hline Polluted river water & Human diseases; no water access points, lack of sewage system, garbage collection (details limited in draft PRA). & & 8 & \\
\hline $\begin{array}{l}\text { Sand scooping (extraction from } \\
\text { the river) }\end{array}$ & $\begin{array}{l}\text { Related to unemployment; rising demand for sand; laxity in enforcing rules; destroys roads, makes river dirty; } \\
\text { causes land slides, deaths, \& devaluation of land. }\end{array}$ & 3 & & \\
\hline $\begin{array}{l}\text { Weak community water } \\
\text { institutions }\end{array}$ & $\begin{array}{l}\text { Low income; low level of skills to start income generating project; lack of trust among members; poor leadership; } \\
\text { poor project management. }\end{array}$ & & 3 & \\
\hline Flooding & $\begin{array}{l}\text { Siltation of river; soil erosion; sand scooping; destruction of vegetation on farms \& on river banks increasing run- } \\
\text { off to river; rip. veget. removal related to fuel wood gathering, tree felling, \& tree dying from root/bark removal. }\end{array}$ & 4 & & \\
\hline Electricity & In village but not connected to houses. & & & 4 \\
\hline Weak Nakuru County Council & Lack of sewage system, garbage collection. (details missing in draft PRA) & & 5 & \\
\hline Insecurity & Unemployment; drunkenness. & & & 5 \\
\hline Unemployment & No jobs & & & 5 \\
\hline Lack Riparian Management Plan & Lack of knowledge; lack of ownership of riparian zone. & & 6 & \\
\hline Dumping & Attitude. & & & 6 \\
\hline Livestock diseases & Plastic papers; outbreaks; expensive drugs. & & & 7 \\
\hline $\begin{array}{l}\text { Lack of extension services (soil } \\
\text { erosion) }\end{array}$ & Extension officers never seen; steep slopes; lack of terraces. & & & 8 \\
\hline Poor roads & $\begin{array}{l}\text { Erosion causes pot holes; no bridges, Njoro R. blocks access to Egerton U. for many residents who work at U.; lack } \\
\text { of culverts. }\end{array}$ & & & 8 \\
\hline Seasonality of fodder & (details missing in draft PRA) & & 9 & \\
\hline Inadequate infrastructure & No water access points, inadequate bridges, lack of storage facilities. (details limited in draft PRA) & & 10 & \\
\hline
\end{tabular}

$\mathrm{B}=$ Barut, $\mathrm{R}=$ Rumwe (Njoro), $\mathrm{M}=$ Mwigito (Njoro) 
Community problems, causes, and priorities. Community problems and priorities for resource management along the River Njoro are listed in Table 3. Water scarcity and water quality problems for human and livestock health, and fuel wood scarcity are top-ranked problems in two of the three communities so far investigated. Waterrelated diseases appear to be widespread, and have emerged as a priority problem in all three communities located in the mid and lower watershed where PRA activities have been completed. One underlying cause of high rates of water-related diseases in the watershed is very poor access to safe water supplies, resulting in consumption of faecally contaminated drinking water and insufficient quantities for basic personal and domestic hygiene. Domestic water supply infrastructure is inadequate in nearly all communities where significant sections of the population, mostly the poorest, collect and transport water by hand from the river or from communal boreholes where water charges are relatively high. Evidence from Egerton University indicates that groundwater, the main developed domestic water supply source in the watershed, may also be contaminated by faecal matter, and if untreated, poses a health risk.

Community health problems identified in discussions so far include: Typhoid (Barut, Mwigito, Nessuit), Diarrhea (Barut, Mwigito), Amoebas (Rumwe), Eye infections (Rumwe), HIV/AIDS (Barut), Malaria (Barut, Rumwe, Mwigito), and Pneumonia and flu (Barut, Rumwe, Mwigito). Research is underway to identify water-related disease patterns in the watershed, focusing on typhoid and diarrhea diseases.

Community proposed actions. The PRA exercises ended with group appraisal of potential solutions to identified problems. A number of common themes emerged from both PRA discussions and initial stakeholder workshops. These included:

- Restoring and protecting the riparian buffer reserve (zoning riparian areas)

- Local enforcement of laws on river pollution (e.g., community patrols)

- Education, awareness raising, and training on need for and rules to protect riparian buffer, trees, river water, among other topics

- Infrastructure rehabilitation and new construction for water supply and sanitation

- Agroforesty and riparian tree planting programs

- Developing a riparian management plan for the watershed

- Clarification and enforcement of laws governing water abstractions from the river

Additional actions were proposed by one or two communities:

- Creation of a watershed-wide umbrella organization

- Income generating activities

- Conservation of the remaining forest catchment area

- Identification of external sources of funding for infrastructure, education campaigns, and training workshops

- Erosion control to protect water quality:

- rehabilitate roads, improve designs and install drainage systems

- improving on-farm soil management

Some of these actions, particularly the first five, were proposed in all communities so far assessed, including in planning meetings in Ngata and Nessuit. Others, for example, infrastructure rehabilitation and construction, often referred to very specific local projects. However, construction of off-river watering troughs and dams for livestock was widely proposed across the watershed. We plan to concentrate 
interventions and watershed action plans around those topics identified by the various communities as priority actions, such as the development of a riparian management plan that includes water pollution protection since most communities identified this as a high priority. The goal of this project is to use stakeholder involvement and a supporting program of watershed research to guide the formation of practical, functional, and sustainable community-based watershed action plans. These preliminary findings indicate the most promising directions for implementing this strategy and enhancing the health and livelihoods of people and communities within the watershed.

\section{References}

Carlson, C. (1999) "Situation Assessment for a Consensus Process." Getting the Most out of Collaborative Stakeholder Processes: A Training Manual. Policy Consensus Initiative, Santa Fe, NM, 3.10-3.13.

CBS (2003) Central Bureau of Statistics, Kenya. http://www.cbs.go.ke/

Chemelil, M.C. (1995) The Effects of Human-Induced Watershed Changes on Streamflows. $\mathrm{PhD}$ Dissertation, Loughborough University of Technology, UK.

Chambers, R. (1992) Rural Appraisal: Rapid, Relaxed and Participatory. Discussion Paper \#311, Institute of Development Studies, Sussex, UK.

Collentine, D., et al. (2002) "CATCH: decision support for stakeholders in catchment areas." Water Policy, Elsevier, 4, 447-463.

Daniels, R. \& T.J. Bassett (2002) "The Spaces of Conservation and Development around Lake Nakuru National Park, Kenya." Professional Geographer, AAG, 54(4), 481-490.

Huckett, S., et al. (2003) "Comparing processes for stakeholder participation in communitybased watershed programs." Paper presented at $7^{\text {th }}$ Int'1 Rangelands Congress, July 26Aug.1, 2003, Durban, South Africa.

ILRI (2002) Mapping Poverty and Livestock in the Developing World. Report commissioned by UK DFID. Int'1 Livestock Research Institute, Nairobi, Kenya. (http://www.ilri. cgiar.org/InfoServ/Webpub/fulldocs/mappingPLDW/index.htm - Feb. 9, 2004)

Kujinga, K. (2003) "Decentralizing water management: an analysis of stakeholder participation in the management of water in Odzi subcatchment area, Save Catchment." Physics \& Chem. of the Earth, Elsevier, 27, 897-905.

Leach, W.D. \& P.A. Sabatier (2003) "Building trust within community-based collaboratives: Watershed partnerships in California and Washington." Paper presented at CommunityBased Collaboratives Research Consortium Workshop, Sept 14-16, 2003, Snowbird Center, Utah. (http://www.cbcrc.org/ 2003speakerpapers/Leach.pdf - Feb. 5, 2004)

Mostert, E. (1998) “A Framework for Conflict Resolution." Water Int'l., 23(4), 206-215.

Lelo, F. et al. (2000) PRA Field Handbook for Participatory Rural Appraisal Practitioners, $3^{\text {rd }}$ ed. Egerton University, Njoro, Kenya.

SAPS-JBIC (2002) Final Report - SAPS Greater Nakuru Water Supply Project, Kenya. Japan Bank for International Cooperation, January 2002.

Smolko, B.A., et al. (2003) "Creating Meaningful Stakeholder Involvement in Watershed Planning in Pierce County, Washington.” J. Amer. Water Res. Assoc., 38(4), 981-994.

Smutko, L.S., et al. (2002) "Involving Watershed Stakeholders: An Issue Attribute Approach to Determining Willingness and Need." J. Amer. Water Res. Assoc., 38(4), 995-1006.

UNWWAP (2003) Water for People, Water for Life: The UN World Water Development Report. UN World Water Assessment Programme, March 2003. 